\title{
Adopting Full Dollarization in Postconflict Economies: Would the Gains Compensate for the Losses in Liberia?
}

Jiro Honda and Liliana Schumacher 



\title{
IMF Working Paper
}

African Department

\section{Adopting Full Dollarization in Postconflict Economies: Would the Gains Compensate for the Losses in Liberia?}

\author{
Prepared by Jiro Honda and Liliana Schumacher ${ }^{1}$
}

Authorized for distribution by Arend Kouwenaar

March 2006

\begin{abstract}
This Working Paper should not be reported as representing the views of the IMF. The views expressed in this Working Paper are those of the author(s) and do not necessarily represent those of the IMF or IMF policy. Working Papers describe research in progress by the author(s) and are published to elicit comments and to further debate.

This paper discusses whether adopting the U.S. dollar as the sole legal tender could help Liberia, a postconflict economy, to boost growth and strengthen fiscal discipline. In view of the performance of exchange rate regimes in many countries and Liberia's own experience with dollarization, we conclude that Liberia should not adopt full dollarization for the following reasons: (i) the alleged benefits voiced by the proponents of dollarization, in terms of enhanced fiscal discipline and faster economic growth, are not supported by the empirical evidence; (ii) dollarization would increase the Liberian economy's vulnerability to external shocks and Liberia's social fragility; (iii) banks in fully dollarized economies face additional capitalization requirements that Liberian banks cannot meet at present; and (iv) dollarization would be costly in terms of real resources because of the loss of seigniorage.
\end{abstract}

JEL Classification Numbers: E58, N17

Keywords: Dollarization, postconflict economy

Author(s) E-Mail Address: 1schumacher@imf.org; jhonda@imf.org;

\footnotetext{
${ }^{1}$ We thank our colleagues Arnim Schwidrowski, Anne-Marie Gulde, Wayne Mitchell, Michael Tharkur, Peter Stella, Arend Kouwenaar, and Arto Kovanen for useful discussions and comments, and are also grateful for editorial support by Elisa Diehl and Elizabeth Larouer.
} 
Contents

Page

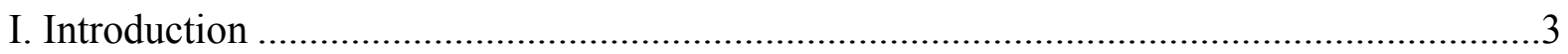

II. Pros of Dollarization: Analytical Considerations and Empirical Evidence ........................4

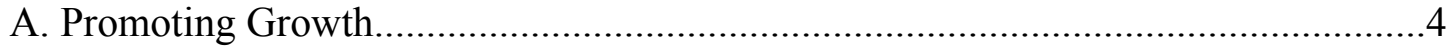

B. Dollarization and Fiscal Discipline ..........................................................

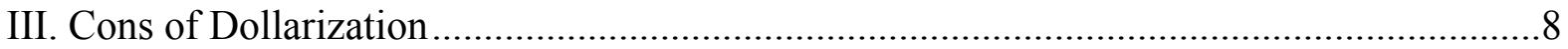

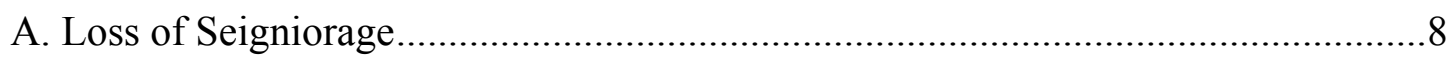

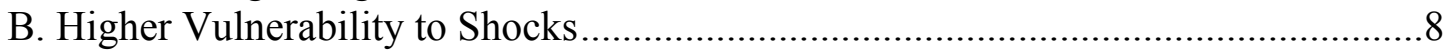

C. Burden on the Banking System ................................................................. 10

IV. Choices of Currency Regimes in Postconflict Countries .............................................11

V. Conclusions: Is Liberia a Candidate for Full, De Jure Dollarization? .............................13

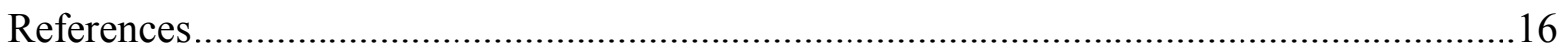

Tables

Table 1. Bank Capitalization and Liquidity in Three Dollarized Economies: Ecuador, El Salvador, and Panama ..............................................................................................11

Table 2. Foreign Exchange Regime Before and After Conflict.........................................12

Table 3. Projected Loss of Seigniorage in Liberia........................................................14

Figures

Exchange Rate Developments Before and After the Conflict, 2001-05 .............................15

Appendices

I. Fiscal Performance in Developing Countries (1998-2003) .............................................18

II. Fiscal Discipline in Developing Countries by Subperiods............................................19

III. Liberia's Historical Experience with Dollarization ................................................20 


\section{INTRODUCTION}

Dollarization is a portfolio shift from domestic currency to foreign currency. The process of dollarization could be total or partial and de jure or unofficial, by which a country adopts a foreign currency as its legal tender.

The idea that officially adopting full, de jure dollarization can be beneficial for some countries is relatively new. Until recently, most of the debate about dollarization focused on partial dollarization as a response to episodes of high inflation. After many emerging market economies with pegs and crawling pegs suffered speculative attacks in the 1990s and more recent years, many economists have moved to the view that intermediate exchange rate regimes are inherently vulnerable, with some economists favoring complete flexibility and others favoring hard pegs (the so-called bipolar view). In this context, full dollarization is the hardest peg imaginable.

In postconflict countries, the choice of an exchange rate regime is often an issue for discussion, as a result of the usual loss of confidence in the existing currency during the conflict. In light of the chaos at a postconflict stage, building such confidence through ongoing efforts for sound economic management may appear a far-reaching task, particularly in light of weak institutional capacity. Under such circumstances, a move to full dollarization is often seen as a quick solution to regain confidence.

The dollarization debate, centering primarily on emerging markets, has so far not systematically explored the pros and cons for postconflict economies of adopting the U.S. dollar as legal tender. This does not mean, however, that postconflict countries' authorities, donors, and multilateral institutions have not considered dollarization at the time the reconstruction work started. The choice has been available, but decisions may have been made without fully exploring the pros and cons of full dollarization in a postconflict environment. We have tried to fill this gap with this paper.

This paper explores in particular the pros and cons for Liberia of adopting full (de jure) dollarization, as opposed to developing domestic monetary institutions and setting up instruments of monetary policy. Since Liberia is already "de facto" highly dollarized, the question for Liberia is whether there are arguments to reinforce the current market tendency for currency substitution or there are gains to make from establishing credibility in a domestic currency.

Though this paper solely focuses on Liberia, where an adoption of full dollarization was seriously discussed at its postconflict stage, the discussions and analysis in this paper may also be applied to other postconflict economies. ${ }^{2}$ All of these economies critically need to

\footnotetext{
2 The IMF staff report on Liberia's 2005 Article IV consultation (http://www.imf.org/external/pubs/ft/scr/2005/cr05166.pdf), published in May 2005, reported the discussions with the Liberian authorities on the adequacy of full dollarization. Some Liberian officials argued that full dollarization could help reestablish fiscal discipline and
} 
achieve fast and sustainable economic growth, and strengthen their institutions. They also share the common challenge of reconstructing their infrastructure and rule of law under extreme difficulties due to a fragile social fabric, weak governance, and low institutional capacity. It is common to hear voices that support dollarization of postconflict economies as a means to establish a basis toward these goals.

This paper is organized as follows: Sections II and III review the pros and cons of fixed and of floating exchange rate regimes and the associated empirical evidence, as dollarization is one type of fixed exchange rate regime. Section IV discusses other postconflict economies' choices of exchange rate regimes. Sections V concludes with an assessment on whether Liberia could benefit from adopting the U.S. dollar as its sole legal tender.

\section{Pros of Dollarization: Analytical Considerations And EMPIRICAl Evidence}

Theoretically, full dollarization represents a trade-off between potential gains and losses. Specifically, full dollarization is expected to impose an iron frame on economic decisions, ensure fiscal discipline, and reduce exchange rate risk. These gains, in turn, would lower interest rates and boost investment, exports, and economic growth. As for losses, dollarization makes the provision of liquidity costly (because of the loss of seigniorage), exposes the economy to higher output volatility in response to real shocks (because of the loss of controls over monetary and exchange rate policy), and increases liquidity risk of commercial banks (in the absence of the central bank's lender of last resort function).

\section{A. Promoting Growth}

Supporters of dollarization argue that it imposes fiscal discipline by providing enhanced policy credibility and time consistency and reduces policy and exchange rate risks, thereby creating better conditions ("a virtuous circle") for sustainable growth. Dollarization, they explain, represents a precommitment mechanism to anchor a country's inflation expectations. Exchange rate risk, which is implicit in "soft" pegs (sharp devaluations), is eliminated. As a consequence, the reduction of policy and exchange rate risks increases the confidence of international lenders and investors in the country, lowering interest rates and, thus, fiscal expenditures and encouraging domestic investment. Finally, higher foreign and domestic investments boost GDP and exports. ${ }^{3}$

attract foreign investors. Others favored dollarization as an effective way to ensure stable prices and wages. The Central Bank of Liberia staff were concerned that full dollarization would preclude more active monetary policies.

${ }^{3}$ For example, see Calvo (1999) and Dornbusch (2001). For complete discussions of the pros and cons of dollarization, see Berg and Borensztein (2000) and Levy Yeyati and Sturzenegger (2003a). For a discussion of de facto and partial dollarization, see Ize and Parrado (2002), De Nicolo and others (2003), Gulde and others (2004), and Ize and Powell (2004). 
Full dollarization would also avoid adverse impacts of "liability dollarization" (that is, financial contracts expressed in U.S. dollars) on growth. Calvo and Reinhardt (2000), for example, argue that soft pegs create a dilemma for central banks in countries with weak currencies, where financial contracts tend to be expressed in U.S. dollars. To avoid large devaluations that could lead to banking and corporate bankruptcies following a negative external shock, central banks set high interest rates, which, in turn, slow down growth.

The empirical evidence is mixed and does not seem to indicate that fixed exchange rate regimes and its hardest version, full dollarization, make a significant contribution to economic growth, although they may contribute to price stability at the expense of higher output volatility. For example,

- Ghosh, Gulde, and Wolf (2002), using the IMF classification of exchange rate regimes and a sample of 147 countries over the 1970-99 period, find the following results:

$\checkmark$ There is no evidence of a strong link between exchange rate regimes and economic growth. The apparent evidence that countries with pegged (and particularly intermediate) regimes grow faster than countries with floating regimes disappears after controlling for country-specific effects and possible simultaneity bias.

$\checkmark$ A rigid exchange rate regime has a positive effect on inflation, across the sample and subsamples and with alternative specifications of inflation. They conclude that this outcome reflects both lower money growth (the discipline effect) and greater confidence in the country (the credibility effect).

Fixed exchange rate regimes and output volatility are strongly correlated when two measures of volatility are used (standard deviations of real GDP and deviations of real GDP from the Hodrick-Prescott filtered trend).

- Levy-Yeyati and Sturzzenegger (2003b), using a de facto classification of exchange rate regimes (that is, a classification that captures the policies implemented by countries regardless of their officially reported regime), study the impact of exchange rate regimes on growth for a sample of 183 countries over the period 1974-2000. They find the following results:

$\checkmark$ In developing countries, less flexible exchange rate regimes are strongly associated with slower growth; in industrial countries, on the contrary, exchange rate regimes do not appear to have any significant impact on growth. These results are robust to endogeneity corrections and a number of alternative specifications borrowed from the growth literature.

$\checkmark$ In developing countries, less flexible exchange regimes are also strongly associated with higher output volatility.

- Rogoff and others (2004), for the same sample and period covered by Ghosh, and others (2002), using both de jure and de facto exchange rate classifications, obtain the following results: 
$\checkmark$ There is no significant relationship between economic growth and the exchange rate regime when developing, emerging market, and developed countries are included in the study. In developing economies, growth appears to decline when the regime is more flexible, though the effect is not statistically significant.

$\checkmark$ Pegged and intermediate regimes tend to have lower inflation in developing countries, perhaps because, in the absence of sound institutions and strong track record, these regimes can enhance policy credibility and discipline monetary policy. But, as countries gain access to international capital markets, there is no evidence that they can reduce inflation by adopting a rigid exchange rate regime.

$\checkmark$ The evidence on growth allows the authors to conclude that the association between lower inflation and exchange rate rigidity does not come at the expense of growth; however, lower inflation is not associated with lower interest rates.

$\checkmark$ There is no relationship between output volatility and exchange rate regimes for developing economies. For emerging markets, output volatility increases with flexibility. This is largely due to volatility that erupts following the collapse of rigid regimes and can be attributed to subsequent, more flexible regimes.

$\checkmark$ The overall conclusion is that, in developing countries with low exposure to capital movements, fixed exchange rate regimes appear to offer some measure of credibility without compromising growth objectives, provided that these countries implement consistent policies.

- Panizza and others (2003), in a study of the costs and benefits of dollarization, compare the output performance of Panama and Belize (both dollarized economies) with that of six other (nondollarized) Central American countries. Their study finds that the standard deviation of output was higher in Belize and Panama in the most recent periods examined in the paper: $1980-89$ and $1990-96$.

- Bordo (1993) compares the performance of different exchange rate regimes for the seven major industrial countries between 1881 and 1989. He compared exchange rate regimes: based on annual data for the gold standard (1881-1913), interwar period (1919-38), Bretton Woods exchange rate system (1946-70), and generalized floating (1974-89). Real output volatility was highest under the gold standard.

\section{B. Dollarization and Fiscal Discipline}

Generally, fixed exchange regimes are expected to impose fiscal discipline. Under fixed regimes, however, fiscal deficits could still be financed by arrears, credit from suppliers and contractors, loans from the domestic banking system, and other forms of domestic and external debt, effectively postponing the costs until the situation becomes unsustainable. Under flexible regimes, the costs of unsound policies are immediately manifested through movements in the exchange rate and the price level. 
Previous empirical research do not support the disciplinary effect under fixed regimes. Vuletin (2003) indicates that, based on an empirical analysis with a sample of 83 countries for the 1974-98 period, fixed regimes do not provide greater discipline, where there is originally no fiscal discipline and the authorities can find ways to finance a fiscal deficit. He further concludes that flexible exchange rates generate greater discipline because of the immediacy of the punishment associated with the unsustainable fiscal policy. Tornell and Velasco (1995) find that countries in CFA franc zone in Africa in the 1980s were notoriously slow in undertaking fiscal adjustment compared with other sub-Saharan African countries operating under flexible exchange regimes. In light of these findings, alleged benefit of fiscal discipline under a fixed exchange regime was not confirmed. Further exploration would be required to verify whether the same view could be held for fully dollarized economy, as full dollarization is expected to have stronger disciplinary effect in the absence of any seigniorage.

In order to test the hypothesis that fiscal discipline is greater in countries adopting full dollarization, we regressed measures of fiscal performance on an exchange rate regime dummy, controlling for level of development and changes in macroeconomic environments. The test is based on a cross-country pooling regression analysis covering 121 emerging market and developing countries for three two-year periods during 1998-2003. Overall deficit and primary deficit, as a percent of GDP, are used to measure fiscal discipline. As explanatory variables, dummy variables representing each exchange rate regime (full dollarization, fixed exchange rate regime, currency board, and currency union) are used, as well as various control variables, including the changes in terms of trade, GDP per capita, inflation rate, level of external debt (in terms of exports), and a dummy variable for IMF program. ${ }^{4}$

The results of this test indicate that the coefficient for the dummy for full dollarization regime is not statistically significant at conventional levels (Appendix I). This result is robust to different vectors of macroeconomic variables, for both the overall and primary balances. Based on the variables that we tested, fiscal performance tends to be better in countries adopting a currency union, which would require a high degree of accountability not only to general public in the country but also to other members of the union. The level of a country's per capita income also plays a critical role for fiscal performance in terms of both overall and primary balances, while the coefficient of a successful IMF program is statistically significant when primary balance is used as a measure of fiscal discipline.

A Chow test to check whether the coefficients are statistically different between periods gives results. The null hypothesis of no difference across the subject pools was rejected at conventional levels for the model using the ratio of overall fiscal balance as an explanatory variable, while the null hypothesis was not rejected for the one using primary balance ratio. To assess the coefficient of full dollarization dummy at each sub period, we further regressed

${ }^{4}$ A dummy for an IMF program has a value of one if the country received financial resources from the IMF during the period, and zero otherwise. 
the fiscal performance, and found that the coefficient of the dummy is still not statistically significant at any period during 1998-2003 (Appendix II).

\section{CONS OF Dollarization ${ }^{5}$}

\section{A. Loss of Seigniorage}

A dollarized economy gives up its seigniorage revenues to the United States. As Berg and Borensztein (2000) highlighted, dollarization involves two kinds of seigniorage loss. The first one is the immediate cost of buying back the local currency in circulation held by the public. The second is the future seigniorage earnings stemming from the flow of new currency printed to satisfy the increase in money demand year after year. ${ }^{6}$ The loss of these seigniorage revenues imposes heavy burdens on a dollarized country, unless it arranges with the country issuing the currency to share the seigniorage. ${ }^{7}$

\section{B. Higher Vulnerability to Shocks}

\section{Loss of Autonomy in Economic Policy Management}

The loss of ability to manage its exchange rate policy and monetary policy makes the dollarized economy vulnerable to external shocks. By definition, a deterioration of the terms of trade lowers real income under any exchange rate regime. However, floating exchange rate regimes make possible a smoother adjustment to a new situation, when the country is hit by an external shock. The exchange rate acts as a shock absorber, allowing the domestic currency to depreciate until external balances are reestablished. Domestic prices in the traded sector would increase and the nominal demand for money would increase. The central bank would typically accommodate the demand and the overall price level would go up, including possibly for the nontradable sector. Real wages would decrease. Over time, and with no need for downward nominal flexibility of prices and wages, tradable goods would see their share of GDP increase. The real sector would not necessarily need to contract.

\footnotetext{
${ }^{5}$ Most of the cons of full dollarization discussed in this section also apply to partially (de facto) dollarized economies. Specifically, partial dollarization constrains monetary policy, exposes banks to systemic liquidity risk and involves a loss of seigniorage, to the extent of the effective currency substitution. In addition, banks in partially dollarized economies are more likely to be exposed to higher currency risk than in fully dollarized economies if they (or their clients) have difficulties in matching the currency of denomination of their assets and liabilities.

${ }^{6}$ For an alternative way to estimate seigniorage in dollarized economies see Schmitt-Grohe and Uribe (1999).

${ }^{7}$ South Africa has agreements with Lesotho and Namibia, where the rand is legal tender, to share seigniorage revenues. The United States has no sharing agreements with countries that use the U.S. dollar as legal tender.
} 
Dollarization helps insulate the economy against domestic nominal shocks, but could, in fact, postpone the adjustment if fiscal policies are inadequate. In a dollarized economy, fiscal mismanagement tends to build imbalances over time since corrections are not immediate (e.g., through a depreciation/devaluation of the nominal exchange rate), as they would be under a floating exchange rate regime or soft peg. ${ }^{8}$ In a fully dollarized economy, instead, excess demand, resulting from an expansionary fiscal policy, would put pressure on nontradable goods, leading to an appreciation of the real effective exchange rate (REER). This, in turn, would lead to a deterioration in the current account and a reduction in the supply of U.S. dollars (the money supply). A fully dollarized economy can give up its nominal exchange rate but not its real exchange rate, and the adjustment process would be postponed.

In a fully dollarized economy, fiscal imbalances can also be absorbed by a reduction in nominal wages or by the existence of potential productivity gains ready to be realized. The ability of dollarization to start this virtuous circle depends on the flexibility of the job market, or the political willingness to introduce difficult labor reforms, or both. In any case, there may be a long lag between the appearance of imbalances and the introduction of corrections. As Rogoff and others (2004) indicate, far from enhancing fiscal governance and good management, dollarization may create incentives for short-lived governments to run large deficits in order to obtain immediate benefits in terms of employment or growth and to disregard the cost of such a policy that, when the regime collapses, will be born by the successor government.

\section{Larger Output Fluctuations}

As highlighted above, in a dollarized economy, output fluctuations would tend to be larger because adjustments to external and domestic shocks require nominal price and wage flexibility. A current account deficit would reduce the money supply. To reestablish equilibrium in the money and goods markets, one or more of these adjustments should take place: (i) nominal wages should fall, (ii) labor taxes should fall (if there is room for this reduction), or (iii) productivity should increase. If any of these adjustments is effected to the extent necessary, exports could regain competitiveness at the new international prices and would represent a larger share of GDP. However, if either nominal downward flexibility or the productivity gains to be realized are insufficient, the real sector will shrink until recession drives nominal wages and prices down. The empirical evidence presented in section II supports the relationship between exchange rate rigidity and output volatility.

\footnotetext{
${ }^{8}$ Under a floating rate regime, fiscal mismanagement would trigger immediate signals of imbalances and (desirable or undesirable) corrections. For example, large fiscal deficits would quickly be corrected by an exchange rate depreciation. Depending on the monetary policy response, the final result would be a combination of a reduction in real GDP and a reduction in inflation. Persistent fiscal deficits under a loose monetary policy would cause people to abandon the local currency (in favor of goods or foreign-currency denominated financial assets).
} 


\section{Burden on the Banking System}

Full dollarization changes the risk profile of banks operating in a dollarized economy. Foreign exchange risk of banks and unhedged corporate clients are eliminated (if banks and corporations borrow and operate only in U.S. dollars). However, risks for banks also increase for several reasons. Bank assets are exposed to high potential losses stemming from higher output volatility. Other things equal, client default is more likely to take place in a dollarized economy since, given that monetary and exchange rate policies cannot provide a buffer against shocks, adjustment to shocks will affect the real sector more directly.

In a dollarized regime, the central bank cannot act as the lender of last resort, due to limited capacity to provide liquidity support for banks. ${ }^{9}$ Since banks typically fund loans (illiquid assets) with liquid liabilities (short-term deposits), the lack of a lender of last resort forces banks to internalize this liquidity risk, which they can do in two ways: (i) through holdings of liquid assets, which allows them to respond to sudden deposit withdrawals; or (ii) with equity, which enables banks to face the losses that would take place if they were forced to sell assets at firesale values in order to respond to a sudden withdrawal of deposits. Both strategies would entail higher cost, which would likely be reflected in higher lending rates.

In practice, because of the high risk exposure, banks in economies without a lender of last resort tend to have high equity and to hold a high proportion of liquid assets. Table 2 shows some prudential indicators for banks in Ecuador, El Salvador, and Panama. In all cases, banks hold a large part of their portfolio in government bonds and exceed the 8 percent capital and 4 percent equity ratios, both minimum ratios recommended by the Basel Committee on Banking Supervision. In Panama, for example, banks' capital ratio is 19 percent, about 95 percent of which is primary capital (i.e., equity). ${ }^{10}$

\footnotetext{
${ }^{9}$ It is even more difficult in a dollarized economy to provide lending of last resort than under the gold standard. As Fischer (1999) notes, when "the Bank of England was bound by gold standard (or currency board) rules, the Bank of course did not have the ability to create gold. ...Nonetheless, ... the Bank of England was given permission to break the gold standard rule, and since Bank of England credit was in the event accepted as being as good as gold, it managed to stop the panics...".

${ }^{10}$ An alternative to a lender of last resort is a strategy to strengthen domestic banks, for example, through higher capital. See Caprio and others (1996).
} 
Table 1. Bank Capitalization and Liquidity in Three Dollarized Economies:

Ecuador, El Salvador, and Panama

(in percent)

\begin{tabular}{lccrrrrrr}
\hline & \multicolumn{2}{c}{ Ecuador } & & \multicolumn{2}{c}{ El Salvador } & & \multicolumn{2}{c}{ Panama } \\
\cline { 2 - 3 } & 2002 & 2003 & & 2002 & 2003 & & 2002 & $2003^{1 /}$ \\
\hline Basel total capital ratio & 11.8 & 12.2 & & 12.1 & 12.8 & 14.5 & 19.0 \\
Tier 1 equity ratio & 9.2 & 10.1 & 9.7 & 9.7 & $\ldots$ & $\ldots$ \\
Liquid assets to total assets ratio & 35.1 & 38.9 & & 30.0 & 31.7 & $\ldots$ & $\ldots$ \\
Liquid assets to deposits ratio & $27.2^{2 /}$ & $28.5^{2 /}$ & & $\ldots$ & $\ldots$ & 29.0 & 24.4 \\
\hline
\end{tabular}

Sources: Ecuador, Superintendencia Nacional de Bancos y Seguros; El Salvador, Superintendencia del Sistema Financiero; Panama, Superintendencia de Bancos; and IMF staff estimates.

1/ September, except capital ratio as of February 2004.

2/ Liquid assets are net of public bonds.

\section{Choices of Currency Regimes in Postconflict Countries}

Postconflict economies pose specific challenges. A conflict often destroys a country's physical and economic structures, and government's capacity to devise and implement sound economic policies. Many people may have been killed, injured, or displaced during the conflict. Serious deficiencies in the health and educational and sanitation standards of the population are observed. A prolonged period of poor humanitarian developments could be a new source of social unrest.

The choice of exchange rate/monetary regime is subject to specific constraints. Some post conflict economies are de facto highly dollarized after the conflict and consequently they have to deal already, to some extent, with many of the disadvantages discussed in the previous sections. But, at the same time, they lack the necessary technical capabilities and the data to implement an independent monetary policy and establish credibility for a domestic currency. Under such circumstances, policy makers in postconflict countries often see dollarization as a policy that can restore confidence quickly while minimizing technical needs.

However, with the exception of Timor Leste and Bosnia and Herzegovina, all recent postconflict countries have favored their own currency. The main reason for deciding against full dollarization appears to be the high costs associated with the adoption of a foreign currency. For example, the Islamic State of Afghanistan considered adopting full dollarization until a new currency was introduced in 2003, but did not explore this option because of the considerable cost of replacing the existing local currency. ${ }^{11}$ Timor Leste was unable to avoid a regime change because of the considerable inefficiencies associated with its

${ }^{11}$ See "Islamic State of Afghanistan: Report on Recent Economic Developments and Prospects, and the Role of the Fund in the Reconstruction Process," IMF Country Report No. 02/219 (Washington: IMF) (http://www.imf.org/external/pubs/ft/scr/2002/cr02219.pdf). 
existing regime, as was Bosnia and Herzegovina, where the use of local currency was unviable because of the complete loss of confidence in it.

Table 2. Foreign Exchange Regime Before and After Conflict

\begin{tabular}{lccc}
\hline & End of conflict & Before conflict & After conflict \\
\hline Sierra Leone & 1999 & Local currency (floating) & Local currency (floating) \\
Guinea-Bissau & 1999 & Local currency (pegged) & Local currency (pegged) \\
Burundi & 2000 & Local currency (pegged) & Local currency (pegged) \\
Eritrea & 2000 & Local currency (floating) & Local currency (floating) \\
Ethiopia & 2000 & Local currency (floating) & Local currency (floating) \\
The DRC & 1999 & Local currency (pegged) & Local currency (floating) \\
& & U.S. dollars used widely & U.S. dollars used widely \\
Kosovo 1/ & 1999 & Local currency (floating) & Local currency (floating) \\
Comoros & 2003 & Deutsche mark used widely & De facto dollarization with DM \\
Timor Leste & 1999 & Local currency (pegged) & Local currency (pegged) \\
Afghanistan & 2002 & Local currency (floating) & Full dollarization \\
Iraq & 2003 & Local currencies (floating) & Local currency (floating) \\
\hline
\end{tabular}

1/ Kosovo is a province of Serbia and Montenegro, currently under temporary UN administration.

Timor Leste adopted full dollarization. During Indonesian rule, the rupee was the sole legal tender and virtually the only currency in circulation in Timor Leste. Following the collapse of the financial system in 1999, however, several currencies began to be used, including the Australian, New Zealand, and U.S. dollars. To eliminate the distortions and inefficiencies associated with the simultaneous circulation of multiple currencies, the U.S. dollar was declared the legal tender of Timor Leste in January 2000. This choice was attributable to the currency's desirable characteristics (stable value, wide international use, and convertibility) and was reinforced by the argument that most of Timor Leste's international trade was denominated in U.S. dollars. The introduction of a national currency was deemed difficult in the absence of a well-developed institutional framework and financial resources to support the value of a new currency.

Bosnia and Herzegovina is an example of a de facto adoption of another country's currency - the deutsche mark (and later, the Euro). However, its local currency, the new Yugoslav dinar, continues formally as legal tender. Since the deutsche mark was already widely used in Bosnia before the conflict, it soon became the dominant currency, and its use was further encouraged by the measurers taken by the UN Interim Administration Mission in Bosnia (UNMIK). The confiscation and freezing of foreign exchange deposits in the early 1990s, the hyperinflation in 1993-94 (with prices rising by 2 percent an hour at its 
peak), and the intensification of ethnic strife eroded confidence in the banking system, leading to a virtual cessation of all noncash transactions. In response to the massive flight to foreign exchange cash holdings and the disappearance of the Yugoslav dinar as a means of transactions, the UNMIK legitimized the use of the deutsche mark.

\section{Conclusions: Is Liberia a Candidate for Full, De Jure Dollarization?}

The August 2003 peace agreement put an end to the civil war in Liberia. However, major reconstruction tasks remain unaccomplished. Overcoming poverty, reversing the dramatic deterioration of living standards, fighting corruption, and restoring good governance practices are the main challenges that lie ahead.

Liberia is at present (end-2005) partially dollarized but in the process of developing a set of monetary instruments and enhancing the attractiveness of its Liberian dollar. Although there are no complete data on the extent of Liberia's "de facto" dollarization, it is likely to be high, taking into account that 80 percent of all bank deposits are denominated in U.S. dollars. However, demand for local currency has rebounded in line with the economic recovery that followed the end of the conflict. Reserve requirements on all bank deposits and foreign exchange auctions are so far the only instruments for monetary policy. Anticipating that a sustained strong demand for local currency would gradually broaden the scope for monetary policies, the Central Bank of Liberia (CBL) has developed a monetary policy framework and is planning to establish a liquidity forecasting system and introduce a credit facility for banks to cushion short-term liquidity shortfalls.

In this setting, some voices, from among the authorities and also the donor community, have proposed that Liberia adopt the U.S. dollar as its sole legal tender, as part of an effort to strengthen fiscal discipline and boost growth.

In view of its economic circumstances, policymakers in Liberia could take into account the following points in considering full dollarization:

- Liberia did not achieve fiscal discipline under the previous dollarization regime (see Appendix II). As Liberia's experience in the 1980s proves, dollarization can coexist for some time with large fiscal deficits. Liberia financed its deficits by accumulating arrears, as well as by borrowing from the domestic banking system (mainly through the central bank).

- Dollarization amplified the macroeconomic consequences of the external shocks that hit Liberia. When the oil crises and global recession of the 1970-80s eroded the trade account, dollarization did not help attract the capital inflows that could have reversed the deterioration in Liberia's balance of payments. Balance of payments deficits led to a drying up of reserves while fiscal deficits and debts became unsustainable. Dollarization became an obstacle because the exchange rate could not adjust to help smooth the consequences of the shocks. In the end, the government abandoned dollarization in a chaotic way in 1988. 
- Given the size of seigniorage relative to GDP and fiscal revenue, full dollarization would be costly for Liberia. The initial cost of replacing the Liberian dollars in circulation would be, at present, about 2 billion Liberian dollars (equivalent to US\$34 million, or 7 percent of GDP), accounting for almost one-half of fiscal revenue. ${ }^{12}$ In addition, the flow cost of dollarization is estimated at US\$5-6 million, or about 1 percent of GDP. In light of Liberia's current fiscal situation, it may be unable to afford a cost of this magnitude.

Table 3. Projected Loss of Seigniorage in Liberia ${ }^{1 /}$

\begin{tabular}{|c|c|c|c|c|c|c|}
\hline & $\begin{array}{c}2004 \\
\text { Act. }\end{array}$ & $\begin{array}{l}2005 \\
\text { Proj. }\end{array}$ & $\begin{array}{l}2006 \\
\text { Proj. }\end{array}$ & $\begin{array}{l}2007 \\
\text { Proj. }\end{array}$ & $\begin{array}{l}2008 \\
\text { Proj. }\end{array}$ & $\begin{array}{l}2009 \\
\text { Proj. }\end{array}$ \\
\hline Stock of Liberian dollar base money & 34 & 39 & 45 & 50 & 54 & 59 \\
\hline (In percent of nominal GDP) & 7.0 & 7.3 & 7.9 & 8.1 & 8.4 & 8.7 \\
\hline (In percent of total fiscal revenues) & 49.5 & 41.4 & 40.1 & 40.0 & 37.2 & 35.1 \\
\hline Creation of Liberian dollar base money & 6 & 5 & 5 & 5 & 5 & 5 \\
\hline (In percent of nominal GDP) & 1.2 & 1.0 & 0.9 & 0.8 & 0.7 & 0.7 \\
\hline (In percent of total fiscal revenues) & 8.4 & 5.4 & 4.7 & 4.0 & 3.3 & 2.7 \\
\hline
\end{tabular}

1/ Projected base money and underlying assumptions for nominal GDP and fiscal revenues are based on the medium-term projections in the IMF staff report on Liberia's 2005 Article IV consultation. Annual real GDP would grow by about 4 percent, insufficient to create significant new employment opportunities and raise living standards. The Report noted that this scenario would likely materialize if the current uneven pace of reforms persists.

2/ Liberian dollar base money are converted into US dollar, using the exchange rate as of end-2004.

- Full dollarization would also have an impact on growth through the bank channel. After the losses they incurred during the war, Liberian banks are now being restructured and recapitalized. Full dollarization would impose an additional burden on them in terms of more stringent solvency conditions and would make financial intermediation more costly (the need to hold higher liquid assets would raise lending rates).

\footnotetext{
12 The annual flow of seigniorage revenue is typically measured as the change in the monetary base; and thus, the present discounted value of future seigniorage can also be estimated (Verde and Veracierto, 2000) with a set of underlying assumptions. To better reflect the expected dynamics of the postconflict economy, however, the paper bases seigniorage estimates on the medium-term projections in the IMF staff report on Liberia's 2005 Article IV consultation (http://www.imf.org/external/pubs/ft/scr/2005/cr05166.pdf).
} 
- Liberia does not currently face a declining confidence in its currency. While the exchange rate had been volatile during and right after the conflict, it has been maintained at a stable level since the end-2003 (Figure).

Figure. Exchange Rate Developments Before and After the Conflict, 2001-05

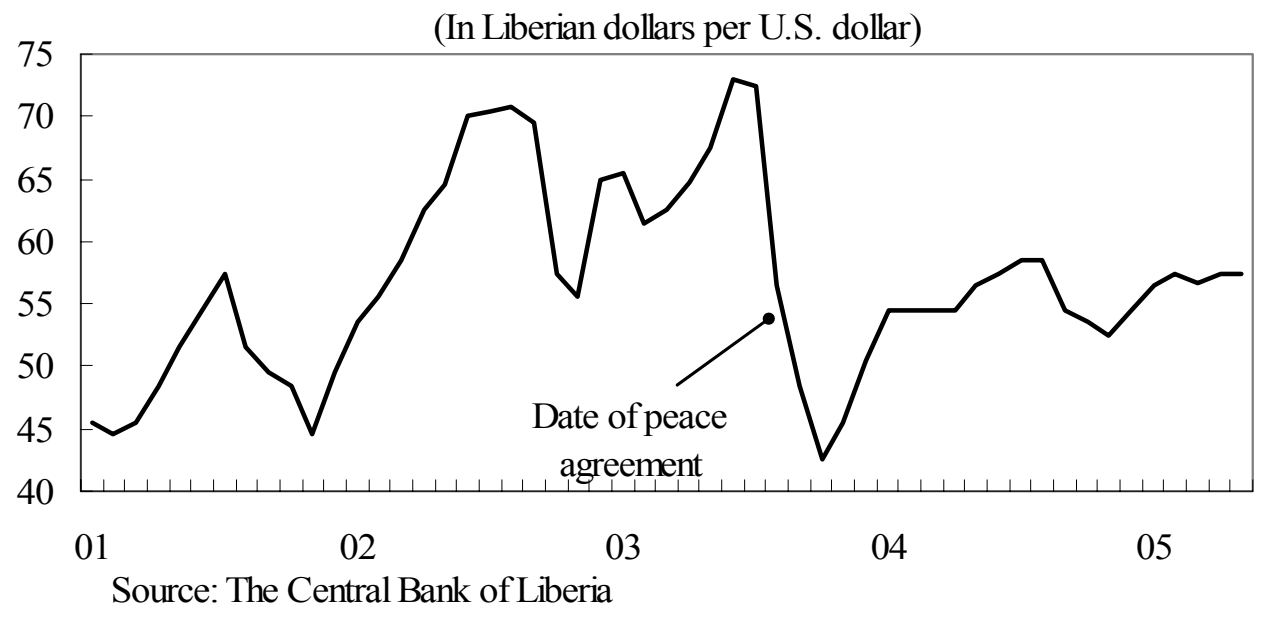

In general, full dollarization would not necessarily contribute to solving the challenges that Liberia faces during its reconstruction. The potential advantages of dollarization-fiscal discipline and stimulus for growth - are not guaranteed. On the other hand, the potential disadvantages of dollarization - higher output volatility (caused by the loss of monetary and exchange rate policy), the additional burden on the banking sector, and the loss of seigniorage - would likely materialize. The current exchange rate regime has enabled Liberia's policymakers to further develop monetary instruments. The development of a set of monetary instruments would give the policymakers tools to smoothen output fluctuations. This could help minimize economic and social disruption, which, in turn, could play an important role in achieving sustainable growth and preserving peace.

Liberia's own experiences in the 1970s and 1980s, when de facto full dollarization was in place, seem to confirm these potential disadvantages. The oil crisis of the 1970s exposed Liberia's vulnerability to external shocks. Because of its social and economic fragility Liberia needs a policy framework which allows adjustment in a way that minimizes adverse effects on output and hence its delicate social fabric; the strong capitalization demands faced by banks in fully dollarized economies cannot meet at present by Liberian banks. Finally, the fact that Liberia was able to run fiscal deficits under full dollarization suggests that full dollarization is not a panacea to the lack of fiscal discipline. 


\section{References}

Berg, Andrew, and Eduardo Borensztein, 2000, "The Pros and Cons of Full Dollarization," IMF Working Paper No. 00/50 (Washington: International Monetary Fund.

Bordo, Michael, 1993, "The Gold Standard, Bretton Woods and Other Monetary Regimes: An Historical Appraisal," NBER Working Paper No. 4310 (Cambridge, Massachusetts: National Bureau of Economic Research).

Calvo, Guillermo, 1999, “On Dollarization” (unpublished; College Park: University of Maryland).

—_, and Carmen Reinhardt, 2000, "Reflections on Dollarization" (unpublished; College Park: University of Maryland).

Caprio, Gerard, Michael Dooley, Danny Leipziger, and Carl Walsh, 1996, "The Lender of Last Resort Function Under a Currency Board: The Case of Argentina," World Bank Working Paper No. 1648 (Washington).

De Nicolo, Gianni, Patrick Honohan, and Alain Ize, 2003, "Dollarization of the Banking System: Good or Bad?” IMF Working Paper No. 03/146 (Washington: International Monetary Fund).

Dornbusch, Rudiger, 2001, "Fewer Monies, Better Monies,” NBER Working Paper No. 8324 (Cambridge, Massachusetts: National Bureau of Economic Research).

Fischer, Stanley, 1999, "The Frequency of Global Crisis Highlights Need to Consider International Lender of Last Resort," paper delivered at the joint luncheon of the American Economic Association and the American Finance Association, New York, January 3 in www.imf.org/external/np/speeches/1999/010399.htm.

Ghosh, Atish, Anne-Marie Gulde, and Holger Wolf, 2002, Exchange Rate Regimes: Choices and Consequences (Cambridge, Massachusetts: MIT Press).

Gulde, Anne-Marie, David Hoelscher, Alain Ize, David Marston, and Gianni De Nicolo, 2004, Financial Stability in Dollarized Economies, IMF Occasional Paper No. 230 (Washington: International Monetary Fund).

Ize, Alain, and Eric Parrado, 2002, "Dollarization, Monetary Policy, and the Pass-Through," IMF Working Paper No. 02/188 (Washington: International Monetary Fund).

Ize, Alain, and Andrew Powell, 2004, "Prudential Responses to De Facto Dollarization," IMF Working Paper No. 04/66 (Washington: International Monetary Fund).

Levy-Yeyati, Eduardo, and Federico Sturzenegger, 2003a, "Dollarization: A Primer," in Dollarization, ed. by Eduardo Levy Yeyati and Federico Stufzenegger (Cambridge, Massachusetts: MIT Press), pp. 1-52.

— 2003b, "To Float or to Fix: Evidence on the Impact of Exchange Rate Regimes on Growth," American Economic Review, Vol. 93, pp. 1173-93.

Panizza, Ugo, Ernesto Stein, and Ernesto Talvi, 2003, "Measuring Costs and Benefits of Dollarization: An Application to Central American and Caribbean Countries," in Dollarization, (Cambridge, Massachusetts: MIT Press) pp. 133-200. 
Rogoff, Kenneth, Aasim Husain, Ashoka Mody, Robin Brooks and Nienke Oomes, 2004, Evolution and Performance of Exchange Rate Regimes, IMF Occasional Paper No. 229 (Washington: International Monetary Fund).

Schmitt-Grohe, Stephanie and Martin Uribe, 1999, "Dollarization and Seigniorage: How Much Is at Stake?” Research Papers (Piscataway, New Jersey: Department of Economics, Rutgers University).

Tornell, Aaron, and Velasco, Andres, 1995, "Fixed Versus Flexible Exchange Rates: Which Provides Mode Fiscal Discipline?” NBER Working Paper No. 5108 (Cambridge, Massachusetts: National Bureau of Economic Research).

Verde, François R., and Marcelo Veracierto, 2000, “Dollarization in Argentina," Economic Perspectives, Federal Reserve Bank of Chicago, Vol. 24 (First Quarter), pp. 24-35.

Vuletin, Guillermo J., 2003, "Exchange Rate Regimes and Fiscal Performance: Do Fixed Exchange Rate Regimes Generate More Discipline Than Flexible Ones?" (College Park: University of Maryland). 
Table. Fiscal Discipline in Developing Countries (1998-2003)

\begin{tabular}{|c|c|c|c|c|c|c|c|c|c|c|}
\hline & \multicolumn{10}{|c|}{ Primary fiscal balance/GDP } \\
\hline & \multicolumn{2}{|c|}{$\begin{array}{c}1 \\
\end{array}$} & \multicolumn{2}{|l|}{2} & \multicolumn{2}{|c|}{3} & \multicolumn{2}{|l|}{4} & \multicolumn{2}{|l|}{5} \\
\hline & Coefficient $\mathrm{T}$ - & T-statistics & Coefficient $\mathrm{T}$ & T-statistics & Coefficient $\mathrm{T}$ & T-statistics & Coefficient 1 & T-statistics & Coefficient $\mathrm{T}$ & T-statistics \\
\hline \multicolumn{11}{|l|}{ Exchange rate regime dummies } \\
\hline Dollarization & 0.018 & 0.65 & 0.016 & 0.54 & 0.018 & 0.66 & 0.012 & 0.51 & 0.012 & 0.50 \\
\hline Currency union & 0.022 & $2.72 * * *$ & 0.020 & $2.42 * * *$ & 0.020 & $2.43 * * *$ & 0.021 & $2.01 * * *$ & 0.021 & $2.00 * * *$ \\
\hline Currency board & -0.004 & -0.52 & -0.005 & -0.67 & -0.008 & -1.14 & 0.001 & 0.16 & 0.001 & 0.17 \\
\hline Other conventional fixed regimes & 0.002 & 0.37 & 0.003 & 0.50 & 0.007 & 1.08 & 0.000 & 0.02 & 0.000 & 0.03 \\
\hline \multicolumn{11}{|l|}{ Control variables } \\
\hline \multicolumn{11}{|l|}{ Macroeconomic variables } \\
\hline Per capita income & 0.021 & $5.68 * * *$ & 0.019 & $4.47 * * *$ & 0.024 & $4.01 * * *$ & 0.019 & $3.30 * * *$ & 0.019 & $3.32 * * *$ \\
\hline Terms of trade & & & -0.017 & -1.08 & -0.016 & -0.97 & -0.032 & $-1.95 * *$ & -0.030 & $-1.79 * *$ \\
\hline CPI & & & -0.003 & -1.04 & -0.003 & -0.80 & -0.001 & -0.41 & -0.001 & -0.38 \\
\hline External debt (t-1) & & & -0.001 & -0.93 & -0.001 & -0.75 & -0.001 & -0.78 & -0.001 & -0.73 \\
\hline IMF program dummy & & & & & 0.018 & $1.93 * *$ & 0.018 & $1.91 * *$ & 0.018 & $1.91 * *$ \\
\hline \multicolumn{11}{|l|}{ Area dummies } \\
\hline Africa & & & & & & & 0.006 & 0.64 & 0.006 & 0.61 \\
\hline Middle East & & & & & & & 0.061 & $5.15 * * *$ & 0.060 & $5.14 * * *$ \\
\hline South America & & & & & & & 0.018 & $2.12 * * *$ & 0.018 & $2.12 * * *$ \\
\hline Europe & & & & & & & 0.004 & 0.55 & 0.004 & 0.55 \\
\hline \multicolumn{11}{|l|}{ Time dummies } \\
\hline 1998-1999 & & & & & & & & & -0.002 & -0.29 \\
\hline $2000-2001$ & & & & & & & & & 0.004 & 0.59 \\
\hline Constant & -0.182 & -5.73 & -0.163 & -4.28 & -0.209 & -3.75 & -0.181 & -3.54 & -0.182 & -3.61 \\
\hline R-squared & 0.13 & & 0.14 & & 0.16 & & 0.2 & 24 & 0.2 & \\
\hline Number of observation & 363 & & 360 & & 360 & & 360 & 60 & 360 & \\
\hline Number of countries & 121 & & 120 & & 120 & & 120 & 20 & 120 & \\
\hline
\end{tabular}

Note: $* *$ and ${ }^{* * *}$ show that the null hypothesis is rejected at significant levels of $5 \%$ and $1 \%$, respectively.

Table. Fiscal Discipline in Developing Countries (1998-2003)

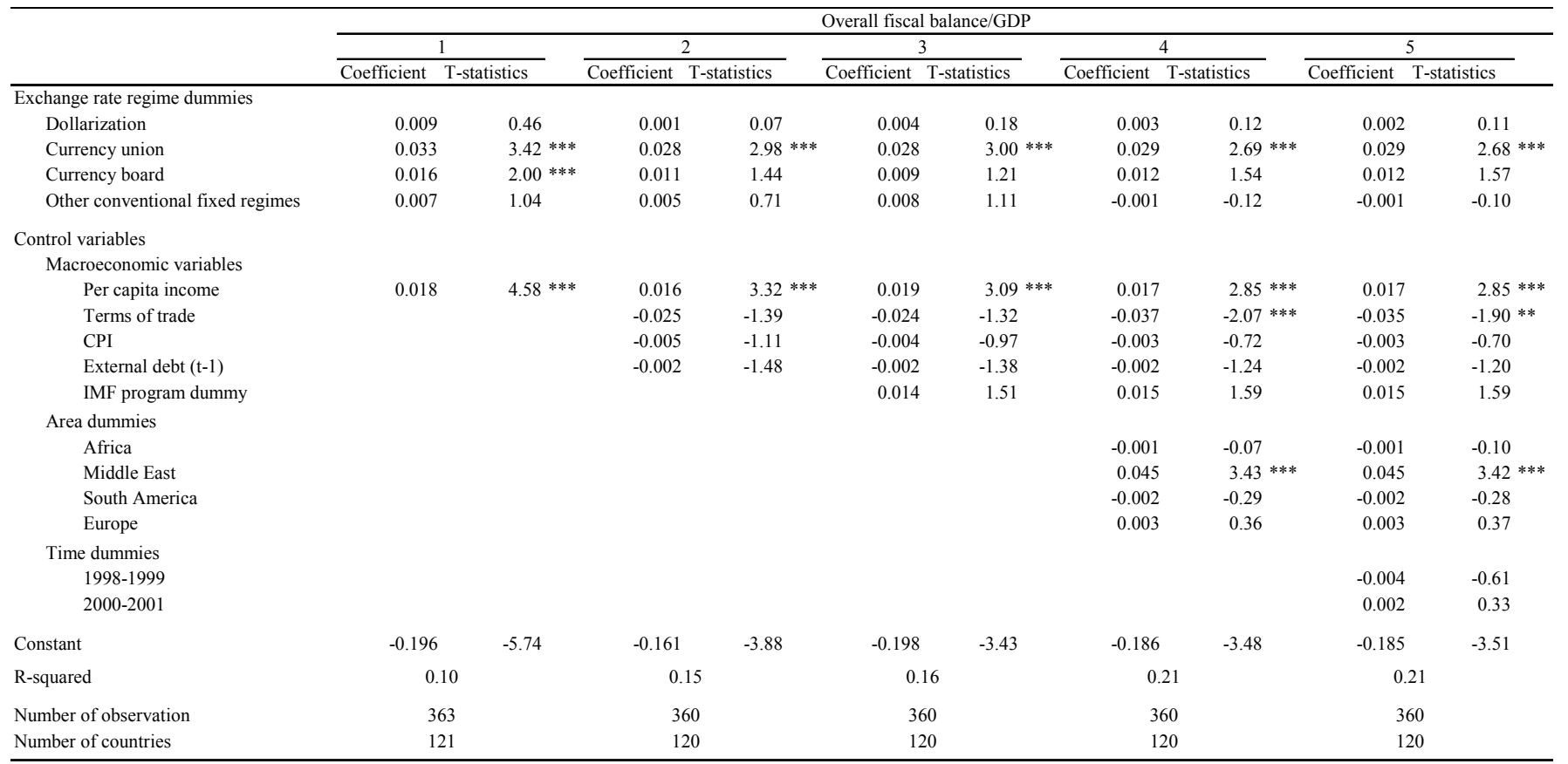

Note: ** and ${ }^{* *}$ show that the null hypothesis is rejected at significant levels of $5 \%$ and $1 \%$, respectively. 
Table. Fiscal Discipline in Developing Countries by Subperiods

\begin{tabular}{|c|c|c|c|c|c|c|c|c|c|}
\hline & \multicolumn{9}{|c|}{ Primary fiscal balance/GDP } \\
\hline & \multicolumn{2}{|c|}{$1998-1999$} & \multicolumn{2}{|c|}{$2000-2001$} & \multicolumn{2}{|c|}{$2002-2003$} & \multicolumn{3}{|c|}{$1998-2003$} \\
\hline & $\begin{array}{ll}\text { Coefficient } \mathrm{T} \\
\end{array}$ & T-statistics & Coefficient 1 & T-statistics & Coefficient & T-statistics & Coefficient & T-statistics & \\
\hline \multicolumn{10}{|l|}{ Exchange rate regime dummies } \\
\hline Dollarization & 0.036 & 0.96 & 0.005 & 0.18 & 0.006 & 0.14 & 0.012 & 0.51 & \\
\hline Currency union & 0.015 & 0.80 & 0.022 & 1.07 & 0.024 & $1.78 * *$ & 0.021 & 2.01 & $1 * * *$ \\
\hline Currency board & 0.000 & -0.02 & -0.002 & -0.15 & 0.007 & 0.74 & 0.001 & 0.16 & \\
\hline Other conventional fixed regimes & 0.010 & 0.71 & 0.002 & 0.17 & -0.014 & -1.21 & 0.000 & 0.02 & \\
\hline \multicolumn{10}{|l|}{ Control variables } \\
\hline \multicolumn{10}{|l|}{ Macroeconomic variables } \\
\hline Per capita income & 0.013 & 1.08 & 0.024 & $2.03 * * *$ & 0.022 & $2.90 * * *$ & 0.019 & 3.30 & $* * *$ \\
\hline Terms of trade & 0.001 & 0.05 & -0.058 & -1.22 & 0.007 & 0.15 & -0.032 & -1.95 & $* * *$ \\
\hline CPI & -0.008 & $-2.00 * *$ & 0.006 & 0.92 & 0.003 & $4.21 * * *$ & -0.001 & -0.41 & \\
\hline External debt (t-1) & -0.001 & -0.29 & -0.002 & -0.73 & 0.000 & -0.27 & -0.001 & -0.78 & \\
\hline IMF program dummy & 0.022 & 0.99 & 0.025 & 1.18 & 0.016 & $1.83 * *$ & 0.018 & 1.91 & $* * *$ \\
\hline \multicolumn{10}{|l|}{ Area dummies } \\
\hline Africa & -0.008 & -0.330 & 0.011 & 0.690 & 0.009 & 0.820 & 0.006 & 0.640 & \\
\hline Middle East & 0.007 & 0.250 & 0.081 & $4.030 * * *$ & 0.071 & $4.020 * * *$ & 0.061 & 5.150 & $* * *$ \\
\hline South America & 0.016 & 0.940 & 0.018 & 1.290 & 0.011 & 0.840 & 0.018 & 2.120 & $* *$ \\
\hline Europe & -0.007 & -0.430 & 0.006 & 0.590 & 0.003 & 0.290 & 0.004 & 0.550 & \\
\hline R-squared & \multicolumn{2}{|c|}{0.16} & \multicolumn{2}{|c|}{0.35} & \multicolumn{2}{|c|}{0.38} & \multicolumn{3}{|c|}{0.24} \\
\hline Number of observation & \multicolumn{2}{|c|}{120} & \multicolumn{2}{|c|}{120} & \multicolumn{2}{|c|}{120} & \multicolumn{3}{|c|}{360} \\
\hline Number of countries & \multicolumn{2}{|c|}{120} & \multicolumn{2}{|c|}{120} & \multicolumn{2}{|c|}{120} & \multicolumn{3}{|c|}{120} \\
\hline
\end{tabular}

Note: ${ }^{* *}$ and $* * *$ show that the null hypothesis is rejected at significant levels of $5 \%$ and $1 \%$, respectively.

Table. Fiscal Discipline in Developing Countries by Subperiods

\begin{tabular}{|c|c|c|c|c|c|c|c|c|}
\hline & \multicolumn{8}{|c|}{ Overall fiscal balance/GDP } \\
\hline & \multicolumn{2}{|c|}{ 1998-1999 } & \multicolumn{2}{|c|}{$2000-2001$} & \multicolumn{2}{|c|}{$2002-2003$} & \multicolumn{2}{|c|}{$1998-2003$} \\
\hline & $\overline{\text { Coefficient } \mathrm{T}}$ & T-statistics & Coefficient & T-statistics & Coefficient & T-statistics & Coefficient & T-statistics \\
\hline \multicolumn{9}{|l|}{ Exchange rate regime dummies } \\
\hline Dollarization & 0.050 & 1.33 & 0.005 & 0.21 & -0.021 & -0.63 & 0.003 & 0.12 \\
\hline Currency union & 0.022 & 1.09 & 0.022 & 1.03 & 0.037 & $2.58 * * *$ & 0.029 & $2.69 * * *$ \\
\hline Currency board & 0.011 & 0.89 & 0.007 & 0.42 & 0.021 & $1.80 * *$ & 0.012 & 1.54 \\
\hline Other conventional fixed regimes & 0.006 & 0.43 & -0.001 & -0.11 & -0.008 & -0.59 & -0.001 & -0.12 \\
\hline \multicolumn{9}{|l|}{ Control variables } \\
\hline \multicolumn{9}{|l|}{ Macroeconomic variables } \\
\hline Per capita income & 0.011 & 0.94 & 0.021 & $1.74 * *$ & 0.019 & $2.15 * * *$ & 0.017 & $2.85 * * *$ \\
\hline Terms of trade & 0.001 & 0.06 & -0.106 & $-1.74 * *$ & 0.015 & 0.29 & -0.037 & $-2.07 * * *$ \\
\hline CPI & -0.011 & $-2.22 * * *$ & -0.007 & -0.86 & 0.004 & $4.50 * * *$ & -0.003 & -0.72 \\
\hline External debt (t-1) & -0.002 & -0.56 & -0.004 & -1.12 & -0.002 & -0.76 & -0.002 & -1.24 \\
\hline IMF program dummy & 0.018 & 0.82 & 0.017 & 0.80 & 0.016 & 1.65 & 0.015 & 1.59 \\
\hline \multicolumn{9}{|l|}{ Area dummies } \\
\hline Africa & -0.019 & -0.840 & 0.008 & 0.460 & 0.003 & 0.270 & -0.001 & -0.070 \\
\hline Middle East & -0.010 & -0.410 & 0.061 & $2.480 * * *$ & 0.003 & 0.270 & 0.045 & $3.430 * * *$ \\
\hline South America & -0.007 & -0.470 & -0.005 & -0.380 & 0.056 & $2.870 * * *$ & -0.002 & -0.290 \\
\hline Europe & -0.012 & -0.770 & 0.003 & 0.230 & -0.006 & -0.460 & 0.003 & 0.360 \\
\hline Adjusted R-squared & \multicolumn{2}{|c|}{0.19} & \multicolumn{2}{|c|}{0.31} & \multicolumn{2}{|c|}{0.30} & \multicolumn{2}{|c|}{0.21} \\
\hline Number of observation & \multicolumn{2}{|c|}{120} & \multicolumn{2}{|c|}{120} & \multicolumn{2}{|c|}{120} & \multicolumn{2}{|c|}{360} \\
\hline Number of countries & \multicolumn{2}{|c|}{120} & \multicolumn{2}{|c|}{120} & \multicolumn{2}{|c|}{120} & \multicolumn{2}{|c|}{120} \\
\hline
\end{tabular}

Note: $* *$ and $* * *$ show that the null hypothesis is rejected at significant levels of $5 \%$ and $1 \%$, respectively. 


\section{LIBERIA'S HISTORICAL EXPERIENCE WITH DOLLARIZATION ${ }^{13}$}

Between World War II and the early 1970s, overall favorable world market conditions for Liberia's exports and foreign direct investment helped sustain a fully dollarized regime, which Liberia had adopted in 1946. Liberia financed its current account deficits through foreign direct investment and foreign loans. Since the government did not maintain official foreign reserves, external equilibrium was automatically maintained through changes in the volume of U.S. dollars in circulation and in the net foreign assets of commercial banks. Following the discovery of iron ore, the first mining concession was awarded in 1946, followed by a large inflow of foreign direct investment, mainly in the mineral but also in the rubber sector. During 1950-62, Liberia's real domestic product increased at least two and a half times, while the value of exports doubled (as a result of sales of iron ore and rubber), and government revenues increased more than ten fold.

In the mid-1960s, real GDP growth flattened following a sharp decline in private investment, as the new iron ore facilities neared completion. At the same time, the rapid expansion of public investment, funded by external and domestic banks, started to put pressure on government finances. In 1962, Liberia became a member of the IMF and, one year later, the government called on the IMF to assist in devising a program of financial reforms and debt renegotiations. A comprehensive financial program was put in place to mobilize additional financial resources, curb expenditure, and terminate reliance on short-term debt. In addition, an agreement was reached with Liberia's major creditors on a rescheduling of debt repayments falling due in the period 1963-68.

Liberia's economic and fiscal performance, benefiting from a global boom for its main export commodities (iron ore and rubber), improved markedly between 1969 and 1974. The rate of growth of real GDP averaged 6 percent. Exports of forestry products, because of an increase in the exploitation of forestry resources, also contributed to Liberia's improved performance. The government ran large surpluses in its current operations that it used to finance development expenditures and applied to debt amortization.

Between 1975 and 1979, the oil crisis and global economic downturn led to a significant slowdown in Liberia, and the rate of real GDP growth averaged slightly over 2 percent (negative real per capita growth). The terms of trade deteriorated while the recession in industrial countries affected Liberia's production of iron ore and rubber, which were exported mainly to European countries. The traditional trade surplus started to decline and became negative in 1976. After years of recording overall surpluses, the central government registered an overall deficit in its operations in 1975-76 as well as in subsequent years, as a result of increases in developmental expenditures and operational losses of public corporations. Overall deficits were financed by foreign resources obtained on concessionary terms and, to a small extent, by commercial loans. In 1977, the government contracted a eurodollar loan, which was used mainly to finance public corporations.

${ }^{13}$ This section is based on IMF staff reports issued between 1969 and 2003. 
A central bank (The National Bank of Liberia) was put in operation in July 1974, but it did not succeed in moderating the consequences of the shock to the terms of trade. The government remained committed to maintaining the U.S. dollar as the predominant means of payment. Since the central bank did not have sufficient reserves to follow countercyclical policies to any significant extent, it was unable to neutralize the impact of the external shock on the economy. Serious liquidity squeezes started to appear that - in the context of rising international rates - put additional pressure on domestic rates and domestic investment.

After 1980, Liberia's internal and external balances rapidly worsened further, and dollarization was eventually abandoned (Box). Political instability, together with a decline in exports due to global recession, declining reserves of iron ore, stagnating rubber production, and a significant decline in the terms of trade, contributed to the collapse of confidence, both internal and external in the Liberian economy. Private capital left the country and investment plummeted. Foreign funding of the rising fiscal and external deficits eventually dried up, and a local currency, the Liberian dollar, was introduced in $1988 .{ }^{14}$

\footnotetext{
${ }^{14}$ Substantial amounts of Liberian dollars were issued to finance the fiscal deficit. Currency reforms took place in 1988, 1992, and 1999. From 1988 to 1992, the "J.J. Roberts" Liberian dollar was issued. Upon the currency reform in 1992, the "Liberty" Liberian dollar was introduced. Both dollars circulated until the current Liberian dollar gradually replaced them during 1998-2000.
} 


\section{Box. Liberia. Fiscal Deficits During the 1980s}

Liberia's overall fiscal deficit rose to more than 10 percent of GDP during the 1980s. This poor fiscal performance was marked by both a steady decline in revenues and a rise in expenditure. Deficits were financed largely through (i) an accumulation of arrears on external debt-service payments and domestic payments arrears (including wages and salaries arrears), (ii) the emergence of various forms of government liabilities (including duty drawbacks and unpaid vouchers owed to suppliers), and (iii) borrowing from the banking system (mainly through the central bank).

Fiscal Balance in the 1980s

(In millions of Liberian dollars)

\begin{tabular}{|c|c|c|c|c|c|c|}
\hline & $1981 / 82$ & $1982 / 83$ & $1983 / 84$ & $1984 / 85$ & $1985 / 86$ & $1986 / 87$ \\
\hline Total revenues (including grants) & 279.3 & 257.4 & 260.1 & 217.0 & 205.6 & 234.6 \\
\hline Total expenditures & 370.6 & 390.4 & 344.1 & 382.6 & 310.5 & 366.3 \\
\hline Overall balance & -91.3 & -133.0 & -84.0 & -165.6 & -104.9 & -131.7 \\
\hline Financing & 91.3 & 133.0 & 84.0 & 165.6 & 104.9 & 131.7 \\
\hline Changes in arrears & -6.0 & 8.0 & 3.3 & 68.7 & 41.1 & 78.0 \\
\hline Borrowing from $\mathrm{NBL}^{1 /}$ & 50.7 & 81.6 & 53.0 & 57.3 & 42.1 & 29.7 \\
\hline Other & 46.6 & 43.4 & 27.7 & 39.6 & 21.7 & 24.0 \\
\hline
\end{tabular}

Sources: Liberian authorities; and IMF staff estimates.

1/ National Bank of Liberia, a former central bank. 
Table. Liberia: Main Economic Indicators, 1966-2004

\begin{tabular}{|c|c|c|c|c|c|c|}
\hline & $\begin{array}{l}\text { Fiscal Deficit } \\
\text { to GDP }\end{array}$ & $\begin{array}{l}\text { Public Debt } \\
\text { to GDP }\end{array}$ & $\begin{array}{l}\text { Annual } \\
\text { Inflation }\end{array}$ & $\begin{array}{l}\text { Growth in } \\
\text { Real GDP }\end{array}$ & $\begin{array}{c}\text { Current Account } \\
\text { Balance }\end{array}$ & $\begin{array}{c}\text { Gross Official } \\
\text { Reserves }\end{array}$ \\
\hline & \multicolumn{4}{|c|}{ (In percent) } & \multicolumn{2}{|c|}{ (In millions of US dollar) } \\
\hline 1966 & $\ldots$ & $\ldots$ & 6.0 & 3.0 & $\ldots$ & $\ldots$ \\
\hline 1967 & $\ldots$ & 68.3 & 6.0 & 3.0 & $\ldots$ & $\ldots$ \\
\hline 1968 & -14.1 & $\ldots$ & 6.0 & 3.0 & $\ldots$ & $\ldots$ \\
\hline 1969 & -2.1 & $\ldots$ & 9.0 & 6.0 & $\ldots$ & $\ldots$ \\
\hline 1970 & 2.5 & 44.5 & 0.8 & 5.2 & $\ldots$ & ... \\
\hline 1971 & 1.9 & 40.8 & 0.1 & 6.5 & $\ldots$ & $\ldots$ \\
\hline 1972 & 3.5 & 35.8 & 3.9 & 7.9 & $\ldots$ & $\ldots$ \\
\hline 1973 & 3.0 & 31.9 & 19.5 & 4.0 & $\ldots$ & 12.1 \\
\hline 1974 & 2.6 & 21.8 & 19.5 & 4.8 & $\ldots$ & 16.6 \\
\hline 1975 & -1.1 & 24.1 & 13.5 & -3.5 & $\ldots$ & 15.7 \\
\hline 1976 & -3.5 & 27.5 & 6.0 & 4.7 & -45.7 & 25.1 \\
\hline 1977 & -8.6 & 31.7 & 5.8 & 1.6 & -104.5 & 27.4 \\
\hline 1978 & -7.7 & 35.3 & 7.1 & 4.8 & -134.7 & 18.0 \\
\hline 1979 & -13.2 & 47.4 & 11.5 & 3.3 & -155.6 & 55.0 \\
\hline 1980 & -7.9 & 53.0 & 14.7 & -4.1 & -132.5 & 4.1 \\
\hline 1981 & -10.2 & 61.2 & 7.6 & -1.0 & -101.4 & 7.4 \\
\hline 1982 & -13.2 & 92.0 & 6.0 & -1.5 & -75.0 & 9.0 \\
\hline 1983 & -15.0 & 100.9 & 2.7 & -4.1 & -29.3 & 9.5 \\
\hline 1984 & -10.5 & 114.6 & 1.3 & -3.1 & -26.5 & 7.8 \\
\hline 1985 & -11.9 & 130.5 & -1.2 & -1.5 & 42.1 & 4.5 \\
\hline 1986 & -8.0 & 159.7 & 4.1 & -0.7 & 64.7 & 4.4 \\
\hline 1987 & -74.1 & 151.7 & 5.0 & 1.8 & -5.8 & 0.4 \\
\hline 1988 & -94.5 & 157.5 & 9.6 & -2.0 & 15.6 & 0.4 \\
\hline 1989 & $\ldots$ & $\ldots$ & $\ldots$ & -26.7 & $\ldots$ & $\ldots$ \\
\hline 1990 & $\ldots$ & $\ldots$ & $\ldots$ & -51.0 & $\ldots$ & $\ldots$ \\
\hline 1991 & $\ldots$ & $\ldots$ & $\ldots$ & -14.2 & $\ldots$ & $\ldots$ \\
\hline 1992 & $\ldots$ & $\ldots$ & $\ldots$ & -35.1 & $\ldots$ & $\ldots$ \\
\hline 1993 & $\ldots$ & $\ldots$ & $\ldots$ & -33.0 & $\ldots$ & $\ldots$ \\
\hline 1994 & $\ldots$ & $\ldots$ & $\ldots$ & -21.8 & $\ldots$ & $\ldots$ \\
\hline 1995 & $\ldots$ & $\ldots$ & $\ldots$ & -4.3 & $\ldots$ & $\ldots$ \\
\hline 1996 & $\ldots$ & $\ldots$ & $\ldots$ & 12.1 & $\ldots$ & $\ldots$ \\
\hline 1997 & 0.0 & 858.8 & $\ldots$ & 106.3 & -201.9 & $\ldots$ \\
\hline 1998 & 0.3 & 694.3 & $\ldots$ & 28.5 & -118.2 & $\ldots$ \\
\hline 1999 & 1.5 & 574.5 & 2.0 & 22.9 & -206.0 & $\ldots$ \\
\hline 2000 & -0.6 & 552.5 & 5.3 & 22.4 & -130.6 & $\ldots$ \\
\hline 2001 & -0.7 & 582.8 & 12.1 & 2.9 & -133.2 & $\ldots$ \\
\hline 2002 & -1.3 & 587.6 & 14.2 & 3.7 & -19.2 & 3.3 \\
\hline 2003 & 0.7 & 807.7 & 10.3 & -31.3 & -79.2 & 7.3 \\
\hline 2004 & -0.1 & 745.1 & 7.8 & 2.4 & -65.5 & 20.0 \\
\hline
\end{tabular}

Source: IMF Staff Reports. 